\title{
STRATEGI PELESTARIAN ARSIP DALAM MENGHADAPI BENCANA DI INDONESIA
}

\author{
Hendra Junawan \\ Mahasiswa Pascasarjana Universitas Islam Negeri Sunan Kalijaga Yogyakarta \\ Konsentrasi Ilmu Perpustakaan dan Informasi \\ hendrajunawan2@gmail.com \\ Rezki Deritani \\ Mahasiswa Pascasarjana Fakultas Matematika Dan Ilmu Pengetahuan Alam \\ Program Studi Ilmu Komputer Universitas Gadjah Mada \\ rezki.nurhadi92@gmail.com
}

\begin{abstract}
ABSTRAK
Melestarikan arsip berarti memastikan bahwa arsip dapat diakses selama diperlukan. Anda dapat melestarikan arsip tercetak dengan melakukan penanganan yang sesuai prosedur dan penyimpanan di lingkungan yang terlindungi dan terkendali. Sedangkan tingkat kerusakan akan berbeda, umur dari arsip Anda dan informasi yang terkandung akan bergantung pada tindakan pelestarian yang Anda terapkan. Bagaimana startegi pelestarian arsip dalam menghadapi bencana di Indonesia. Pada penelitian ini merupakan jenis penelitian lapangan yaitu "kajian pustaka" yang mempunyai sifat deskriptif. Pemeliharaan arsip dilakukan untuk menjamin bahwa arsip disimpan di tempat yang baik dan aman dengan fasilitas yang lengkap dan dapat ditemukan secara cepat. Membuat perencanaan merupakan langkah yang penting untuk diterapkan pada saat terjadi bencana. Insiden yang tiba-tiba atau tidak terduga, alami atau buatan manusia, dapat merusak arsip. Insiden itu bisa merusak fasilitas penyimpanan juga, menghambat upaya penyelamatan dan pemulihan..
\end{abstract}

Kata Kunci: arsip, pelestarian arsip, menghadapi bencana.

\section{PENDAHULUAN}

Keamanan informasi merupakan masalah penting bagi setiap lembaga, khususnya dengan ketergantungan kita pada teknologi untuk melakukan bisnis. Setiap lembaga harus memastikan bahwa informasi dan arsip mereka terjamin keamanannya sehingga arsipnya tidak dapat, 1. Dirusak atau diubah tanpa izin, 2. Dihancurkan tanpa izin, 3. Diakses secara tidak sah. Dalam membuat sistem keamanan arsip, hal yang perlu dipertimbangkan selain mekanisme dalam mengakses arsip, juga perlu dipertimbangkan keberlanjutan sistem tersebut. Sehingga arsip yang tersimpan pada sistem akan selalu dapat diakses. Melestarikan arsip berarti memastikan bahwa arsip dapat diakses selama diperlukan. Anda dapat melestarikan arsip tercetak dengan melakukan penanganan yang sesuai prosedur dan penyimpanan di lingkungan yang terlindungi dan terkendali. Pelestarian arsip digital audiovisual lebih kompleks dari itu. Selain perlu penanganan hati-hati, penyimpanan dalam lingkungan khusus, arsip digital juga harus dipindahkan ke platform baru dengan format baru. 
Hal tersebut dilakukan untuk menghindari kerusakan dan memastikan bahwa informasi yang terkandung dalam arsip terus dapat diakses dan dipahami selama diperlukan. Ingat bahwa arsip anda akan memburuk, apakah arsip bentuk kertas, fotografi, digital atau audiovisual. Sedangkan tingkat kerusakan akan berbeda, umur dari arsip Anda dan informsi yang terkandungnya akan bergantung pada tindakan pelestarian yang diterapkan.

\section{TINJAUAN PUSTAKA}

\section{Arsip}

Arsip merupakan segala bentuk informasi yang telah dibuat, diterima dan disimpan oleh seseorang/lembaga/organisasi yang mempunyai nilai guna sesuai dengan kebutuhan pemustaka yang ingin membutuhkan. Aktifitas organisasi yang berkaitan erat dengan kegiatan dalam pengelolaan arsip. Arsip merupakan salah satu sumber rujukan suatu organisasi yang mengelola arsip, sehingga berjalan dengan baik agar mempunyai nilai guna dalam organisasi tersebut. Arsip menjadi hal yang sangat penting untuk diperhatikan dalam organisasi yang mengelola arsip.

Thomas Wiyasa menyatakan bahwa arsip berasal dari bahasa Yunani yaitu dari akar kata arche, kemudian berubah menjadi nama archea dan setelah itu mengalami perubahan menjadi archeon. Arche yang artinya permulaan berarti fungsi/kekuasaan peradilan. Sedangkan archea yang artinya dokumen atau catatan mengenai permasalahan. Warkat yang dimaksud di sini adalah warkat yang masih mempunyai nilai guna, warkat tersebut dirawat dan dijaga secara sistematis sehingga dapat ditemukan dengan mudah dan cepat apabila pemustaka yang ingin mendapatkan informasi tersebut. Berdasarkan hasil definisi diatas dapat disimpulkan bahwa arsip adalah kumpulan warkat baik melalui gambar ataupun tulisan yang tersimpan secara sistematis dan apabila suatu saat dibutuhkan dapat dimanfaatkan sebagai sumber informasi ataupun sumber rujukan.

\section{Fungsi Pelestarian Arsip}

Arsip merupakan sebuah dokumen yang berisikan informasi-informasi yang dianggap penting sehingga setiap lembaga gencar untuk melindungi bahkan berusaha untuk melakukan pelestarian arsip. Dalam hal ini Karmidi Martoadmojo berpendapat bahwa fungsi dari sebuah pelestarian arsip yaitu untuk menjaga agar sebuah bahan pustaka arsip tidak dirusak oleh tangan jahil, serangga, atau jamur yang meraja lela pada buku-buku yang ditempatkan di ruang-ruang yang memiliki suhu udara yang lembab (Karmidi Martoadmodjo, 1999).

Melindungi dokumen arsip dibutuhkan adanya tindakan-tindakan yang prefentif sehingga dapat mengurangi kerusakan pada sebuah dokumen arsip.(Nurzannah et al., 2017). Dalam hal ini maka fungsi dari sebuah kegiatan pelestarian arsip seperti:

1. Fungsi melindungi, dalam hal ini yang dimaksudkan adalah setiap bahan pustaka arsip wajib dilindugi dari serangan apapun termasuk manusia, sehinga benda-benda perusak lainya tidak dapat menyentuh atau memakan dokumen.

2. Fungsi pengawetan, seperti melakukan perawatan baik-baik, bahan arsippun menjadi awet, dapat lebih lama dipakai, dan sangat diharapkan banyak yang dapat membacanya/menggunakannya. 
3. Fungsi kesehatan, dengan perawatan yang baik maka bahan pustaka menjadi bersih dan terlindungi serta terbebas dari jamur atau sumber sarang yang berpenyakit yang dapat menimbulkan kerusakan.

4. Fungsi pendidikan, dalam hal ini pengguna perpustakaan dan pustakawan hendaknya belajar dan mencari tahu bagaimana perawatan dan pemakaian sebuah dokumen yang baik dan benar sehingga tidak menimbulkan kerusakan.

5. Fungsi kesabaran, hal ini ditujukan kepada para pustakawan/arsiparis dalam proses kegiatan perawatan arsip dengan kesabaran yang baik sehingga tidak menimbulkan sikap yang ceroboh dalam proses preservasi dokumen dan hal ini diyakini juga akan efektif dalam proses perawatan sebuah dokumen arsip itu sendiri dan tidak mudah rusak atau hancur.

6. Fungsi sosial, dalam proses ini pengerjaan dalam proses perawatan bahan arsip tidak bisa dilakukan dengan satu orang saja, melainkan masih membutuhkan beberapa orang dalam fungsi proses pengerjaanya. Hal ini juga dapat memicu kesadaran akan pentingnya keawetan sebuah dokumen arsip.

7. Fungsi ekonomi, dengan kegiatan pelestarian yang baik bahan pustaka menjadi awet dan masalah financial juga dapat dihemat, serta masih banyak aspek lain yang berhubungan dengan pelestarian bahan pustaka (Buedi Martono, 1990)

8. Fungsi keindahan, dengan pelestarian yang baik serta penataan bahan pustaka yang rapih perpustakaan tampak akan jauh menjadi lebih indah sehingga hal ini dapat memicu perhatian masyarakat untuk datang mengunjungi dan membacanya.

\section{Perbaikan Arsip Akibat Bencana}

Perbaikan terhadap sebuah dokumen arsip ataukah melakukan perencanaan terhadap sebuah bencana atau yang sering kita sebut dengan disaster plan program and recovery archives. Dalam hal ini yaitu membuat program untuk bekerja melakukan kegiatan-kegiatan yang berhubungan dengan lembaga kearsipan yang di daerahnya rawan akan terjadinya bencana. Dalam hal ini juga dapat ditemukan kegiatan-kegiatan perbaikan dokumen arsip secara internal dan eksternal pada sebuah lembaga kearsipan.(Verry Mardiyanto, 2016). Menurut ira A penn (1989:148), sebuah organisasi yang merespon manajemen penanggulangan bencana dengan sebuah desain sebagai berikut:

1. Meminimalkan gangguan yang berhubungan dengan operasi bisnis secara normal.

2. Mencegah terjadinya gangguan lebih lanjut

3. Meminimalkan terjadinya dampak bencana pada aspek ekonomi

4. Menyiapkan langkah prosedur alternatif

5. Melatih tim dengan sebuah prosedur gawat darurat sehingga pada saat terjadi bencana setiap orang yang memiliki tanggung jawab terhadap pengamanan bahan arsip akan segera tanggap.

6. Menanggulangi aspek-aspek yang terdampak

7. Mampu menyediakan layanan restorasi dengan baik

Pemeliharaan dan pengamanan arsip dalam upaya untuk mencagah kerusakan diakibatkan oleh bencana serta adanya kegiatan pemeliharaan secara fisik dengan cara melakukan(Ii \& Teori, n.d.):

1. Pengaturan ruangan, arsip selalu dijaga agar tetap kering dan jauh dari udara kelembapan. 
2. Pemeliharaan tempat penyimpanan, maksudnya yaitu arsip perlu disimpan ditempat yang terbuka dan penyusunan arsip juga diberikan jarak.

3. Tindakan preventif yaitu dengan melakukan kegiatan pencegahan serta adanya pelarangan petugas atau siapapun membawa makanan ataupun minuman ke dalam ruangan arsip. Kalau hal ini terjadi maka hanya akan mengundang serangga/hewan yang lainya ke dalam ruangan sehingga lama-lama akan menyebabkan kerusakan.

4. Tempat arsip, hal ini perlu memiliki tempat arsip yang terbuat dari logam, kalaupun terbuat dari kayu maka dilakukan pemilihan jenis kayu yang tidak bisa dimakan rayap. Dengan penyimpanan dokumen arsip yang baik maka dapat mengurangi kerusakan pada arsip itu sendiri.

5. Kebersihan sangat lah penting dilakukan oleh pengelola lembaga arsip sehingga ruangan akan terjaga dan jauh dari serangan serangga dan kotoran. Sehingga dokumen arsip dapat terjaga dan aman dari kerusakan.

\section{METODE PENELITIAN}

Artikel ini ditulis oleh penulis berdasarkan teori yang ditemukan dari beberapa literatur, pengamatan, dan pengumpulan data-data yang diperoleh dari sumber primer dan sekunder serta berbagai tulisan mengenai pelestarian arsip dalam menghadapi bencana di Indonesia. Menurut Sugiyono (2010, hal. 147) analisis deskriptif adalah menganalisis data dengan cara mendeskripsikan atau menggambarkan data yang telah terkumpul sebagaimana adanya tanpa bermaksud untuk membuat kesimpulan yang berlaku umum atau generalisasi.

\section{PEMBAHASAN}

\section{Pentingnya Pelestarian Arsip}

Pelestarian arsip merupakan salah satu tindakan yang biasanya dilakukan oleh tenaga profesional dalam proses penaganan sebuah dokumen arsip baik itu berbentuk fisik maupun dari bentuk informasinya. Pelestarian juga berperan penting dalam hal ini untuk menjaga keaslian sebuah informasi agar tidak mengalami kerusakan(Safri, n.d.) Dalam hal ini tindakan pelestarian bahan pustaka arsip sangat lah penting karena pelestarian ini yaitu sebuah usaha yang dapat mencegah sebuah dokumen yang kita miliki tidak mudah rusak dan sangat diusahakan agar tetap awet dan dapat dipakai dalam jangka waktu yang lama. Dalam pelestarian bahan arsip tentunya perlu melakukan beberapa strategi yang dianggap dapat membantu dalam proses pelestarian sebuah arsip.

Pelestarian arsip perlu memperhatikan beberapa faktor yang dapat menyebabkan arsip itu rusak karena disebabkan oleh berbagai faktor yang diyakini dapat merusak sebuah dokumen arsip. Pelestarian arsip tidak hanya dapat dilihat dengan gamblang perlu adanya analisis dari sebuah kerusakan yang dapat menjadi sebuah alternatif bagi sebuah tenaga profesional dalam proses perbaikan dokumen tersebut. Banyak hal yang dapat kita lakukan dalam proses pelestarian arsip sehingga dokumen yang kita miliki itu tidak mudah mengalami kerusakan. Dalam hal ini ada beberapa strategi yang dapat dilakukan dalam proses pelestarian arsip dalam menghadapi berbagai ancaman bencana di Indonesia. 
Strategi-strategi yang dapat dilakukan dalam pelestarian arsip dalam menghadapi bencana di Indonesia diantaranya yaitu:

\section{Persiapan}

Bencana alam memang tidak dapat kita prediksikan sebelumnya akan tetapi kita sebagai pengelola dokumen negara yang sangat penting perlu melakukan sebuah tindakan persiapan dalam menghadapi terjadinya sesuatu hal yang buruk seperti bencana. Perencanaan juga mengambarkan langkah-langkah atau prosedur persiapan dalam menghadapi sebuah terjadinya bencana (Badan \& Dan, 2015). Dalam hal ini persiapan dalam pelestarian sebuah dokumen arsip perlu melihat dan memperhatikan baik itu dari bentuk fisik sebuah dokumen maupun nilai dan makna dari sebuah informasi yang terkandung didalamnya.

Hal ini tentu membuat para petugas pegelolaan arsip berfikir keras dalam memikirkan bagaimana sebuah arsip dapat dipersiapkan dan ditolong, sehingga informasi yang terkandung didalamnya masih terjaga dan tidak hilang. Dalam melakukan persiapan, kegiatan yang dilakukan adalah:

a) Menempatkan arsip hasil dari akuisisi pada ruang transit untuk diseleksi dan dibersihkan dari berbagai faktor perusakan arsip.

b) Memindahkan arsip yang sudah diseleksi dan dibersihkan ke ruang penyimpanan.

\section{Pemeliharaan}

Pemeliharaan arsip dilakukan untuk menjamin bahwa arsip disimpan di tempat yang baik dan aman dengan fasilitas yang lengkap dan dapat ditemukan secara cepat. Dalam hal ini pemeliharaan dokumen arsip juga dapat dikatakan sebagai suatu proses atau cara untuk menjaga dan merawat arsip (Yayan Daryana, n.d.) Arsip selayaknya sesuatu yang sangat berharga dan bernilai sehingga tempat penyimpananya juga harus bagus dan tidak sembarangan sehingga arsip tetap terjaga dan tidak mudah rusak. Dalam hal ini fasilitas sangatlah berperan penting dalam mengamankan sebuah arsip dokumen baik itu arsip dinamis maupun arsip statis. Dalam pemeliharaan, kegiatan yang dilakukan adalah:

a) Menata arsip sesuai dengan grupnya.

b) Menyimpan dan menata arsip sesuai dengan format dan medianya.

c) Mengatur kestabilan suhu dan kelembaban udara ruang penyimpanan arsip.

d) Mengontrol fisik arsip secara rutin.

e) Mengontrol lingkungan tempat penyimpanan arsip

f) Menindaklanjuti hasil temuan kontrol terhadap fisik dan lingkungan arsip.

\section{Perawatan}

Perawatan arsip yang tepat akan membantu dalam menjaga arsip selama mereka masih dibutuhkan.

a) Pergunakan arsip secara berhati-hati.

b) Pastikan tangan anda dalam keadaan bersih ketika memegang arsip, atau gunakan sarung tangan bila diperlukan.

c) Bawalah arsip tercetak dengan alas yang kaku, terutama dalam jarak jauh atau bila arsip tersebut mudah rusak/rapuh. 
d) Berikan perlindungan pada dokumen untuk melindungi mereka dari abrasi, tinta atau bahan perekat yang dapat merusak dokumen.

e) Gunakan troli dengan alas datar ketika membawa arsip berukuran besar.( Dewi Ladiawati2007)

\section{Tahap Pencegahan}

Graham Mattews dan John Feather, dalam bukunya "Disaster Management for Libraries and Archives" menyebutkan tahap yang pertama dilakukan dalam kesiapsiagaan menghadapi bencana adalah pencegahan (prevention). Tahap pencegahan dilakukan dengan pemeliharaan rutin pada bangunan penyimpanan arsip. Meskipun pemeriksaan rutin selalu dilakukan, suatu peristiwa bencana dapat terjadi kapan saja. Tahap pencegahan dilakukan dengan melakukan pengamatan langsung terhadap lingkungan penyimpanan arsip. Pemeriksaan yang dilakukan secara rutin dengan mengamati lingkungan gedung tempat penyimpanan arsip. Dalam hal ini tahapan pencegahan kerusakan arsip yang disebabkan oleh dampak bencana alam sehingga dapat mengurangi resiko kerusakan yang lebih parah, tentunya hal ini diakukan dengan cara memperhatikan ruang penyimpanan sebuah dokumen arsip (Wigati \& Rachman, 2019)

\section{Tahap Kesiapsiagaan}

Tahap Kesiapsiagaan "Preparadness" merupakan perencanaan penyelamatan bencana pada arsip. Membuat perencanaan merupakan langkah yang penting untuk diterapkan pada saat terjadi bencana. Dengan tindakan yang terencana maka dapat mengurangi resiko arsip yang seharusnya rusak akibat bencana.( Arsip.ui.ac,id) Selain itu, perencanaan yang baik merupakan pedoman bagi staf pada proses penyelamatan arsip. Dengan adanya perencanaan, setiap staf dapat melakukan tindakan penyelematan arsip sesuai instruksi dan prosedur yang telah ditetapkan. Menurut Dawson mengatakan elemen dasar yang perlu dilakukan dalam tahap kesiapsiagaan, sebagai berikut:

a) Pembuatan prosedur penanganan bencana.

b) Pembentukan komite penaganan bencana.

c) Melakukan pelatihan untuk konservator dan tim pemulihan bencana.

d) Membuat daftar kontak yang dapat dihubungi.

e) Menyiapkan peralatan untuk perbaikan dan restorasi arsip.( Akbar Rizky Rifai, 2016)

Selain penjelasan diatas maka tanggap bencana juga menghadirkan alternatif atau cara yang dilakukan seperti mitigasi bencana dalam sebuah gedung arsip. Mitigasi bencana ini kenapa sangat penting karena dapat meminimalkan kerusakan yang diakibatkan oleh bencana, ketika kita tidak pernah berusaha untuk memikirkan kemungkinan yang terjadi seperti bencana maka dapat diperkirakan ketika dampak bencana itu datang maka kemungkinan yang terjadi kita hanya mengalami kesulitan yang sangat rumit dalam mengatasi sebuah arsip yang rusak (Agustiawan, 2018)

Tujuan dalam sebuah mitigasi bencana adalah salah satu upaya yang dilakukan dalam mengurangi dampak yang ditimbulkan, khususnya pagi para penduduk yang menjadi sebagai landasan perencanaan pembangunan, dalam hal ini juga dapat meningkatkan pengetahuan masyarakat dalam menghadapi dan mengurangi dampak/resiko bencana. 
Beberapa strategi yang dapat dilakukan dalam proses mitigasi bencana antara lain adalah:

a) Pengenalan dan pemantauan risiko bencana

b) Perencanaan partisipatif penanggulangan bencana

c) Penerapan upaya fisik, nonfisik, dan pengaturan penanggulangan bencana

d) Pegembangan budaya sadar bencana pengawasan terhadap pelaksanaan tata ruang dan pengelolaan lingkungan hidup

e) Identifikasi dan pengenalan terhadap sumber bahaya atau ancaman bencana.

\section{Tahap Reaksi}

Tahap reaksi "Response" merupakan kegiatan yang dilakukan sebelum, sesudah, atau langsung setelah kejadian bencana untuk mengurangi kerusakan. Tahap reaksi merupakan implikasi dari tahap kesiapsiagaan menghadapi bencana yang telah dibuat sebelumnya. Aktifitas pada tahap reaksi yang dilakukan dengan mengenali keadaan darurat, menghubungi komite, penanganan bencana dan menjalankan perancanaan bencana. Tahap respon atau reaksi yang dilakukan pada saat terjadi bencana, sebagai berikut:

a) Menghubungi komite penanganan bencana

b) Melakukan tindakan jangka pendek yang diambil oleh konservator dan penanganan terhadap bangunan penyimpanan arsip.

c) Melakukan tindakan jangka panjang yang berkaitan dengan prioritas penanganan bencana, penyelamatan arsip yang melibatkan tim pemulihan bencana dan konservator.

\section{Tahap Pemulihan}

Tahap pemulihan "Recovery" merupakan upaya yang dilakukan untuk mengembalikan arsip yang terdapat pada organisasi agar digunakan kembali. Pemulihan berkaitan dengan penyelamatan jangka pendek dan jangka panjang terhadap koleksi arsip yang mengalami kerusakan. Dalam proses pemulihan ini harus sesuai dengan prosedur yang sudah ditetapkan dan tidak sembarangan dalam melakukan pemulihan sebuah dokumen arsip. Pemulihan juga sangat menjadi perhatian dalam hal ini baik itu dalam jangka yang pendek maupun dalam jangka yang sangat panjang. Adapun tujuan dari pemulihan sebuah arsip yaitu untuk mengurangi kerusakan yang terdapat pada arsip dinamis maupun statis, itulah sebabnya kenapa perlu dilakukannya sebuah pemulihan atas sebuah dokumen. Dalam hal ini pemulihan yang dilakukan, sebagai berikut:

a) Memperbaiki tempat penyimpanan arsip yang rusak akibat bencana.

b) Mengevaluasi teknik penyelamatan arsip yang dilakukan tim pemulihan dan konservator.

\section{Rekam Dalam Keadaan Darurat}

Insiden yang tiba-tiba atau tidak terduga, alami atau buatan manusia, dapat merusak arsip. Insiden itu bisa merusak fasilitas penyimpanan juga, menghambat upaya penyelamatan dan pemulihan. Respons yang terencana dengan baik sangat penting untuk mengurangi tingkat kerusakan dan kehilangan arsip. 
a) Mempersiapkan

Mengurangi kerusakan dan kehilangan, dan mengendalikan biaya penyelamatan dan pemulihan, dengan melakukan catatan perencanaan darurat, sebagai berikut:

1. Mendokumentasikan dan mengelola faktor risiko.

2. Mengembangkan rencana darurat rekaman tertulis untuk mengelola arsip, penyelamatan arsip, dan upaya pemulihan arsip.

3. Melatih anggota staf, dalam mengimplementasikan rencana penyelamatan.

b) Menangani

Langkah dalam mengimplementasikan rencana darurat rekaman arsip sebagai berikut:

1. Pastikan area aman pada kondisi kebakaran.

2. Menilai dan mendokumentasikan tingkat dan jenis kerusakan.

3. Mengidentifikasi prioritas dan sumber daya yang tersedia.

4. Mengidentifikasi saran dan layanan pemulihan arsip yang dibutuhkan.

5. Menyiapkan rencana setelah kerusakan arsip.(www.archives.gov)

\section{PENUTUP}

Melestarikan arsip berarti memastikan bahwa arsip dapat diakses selama diperlukan. Anda dapat melestarikan arsip tercetak dengan melakukan penanganan yang sesuai prosedur dan penyimpanan di lingkungan yang terlindungi dan terkendali. Pemeliharaan arsip dilakukan untuk menjamin bahwa arsip disimpan di tempat yang baik dan aman dengan fasilitas yang lengkap dan dapat ditemukan secara cepat. Perawatan arsip yang tepat akan membantu dalam menjaga arsip selama mereka masih dibutuhkan.

Tahap pencegahan dilakukan dengan pemeliharaan rutin pada bangunan penyimpanan arsip. Tahap Kesiapsiagaan "Preparadness" merupakan perencanaan penyelamatan bencana pada arsip. Membuat perencanaan merupakan langkah yang penting untuk diterapkan pada saat terjadi bencana. Dengan tindakan yang terencana maka dapat mengurangi resiko arsip yang seharusnya rusak akibat bencana. Tahap pemulihan "Recovery" merupakan upaya yang dilakukan untuk mengembalikan arsip yang terdapat pada organisasi agar digunakan kembali. Insiden yang tiba-tiba atau tidak terduga, alami atau buatan manusia, dapat merusak arsip. Insiden itu bisa merusak fasilitas penyimpanan juga, menghambat upaya penyelamatan dan pemulihan.

\section{DAFTAR PUSTAKA}

Akbar, Rizky Rifai. (2016). Perlindungan Arsip (Studi Kasus Di BPAD Pemerintah Provinsi DKI Jakarta, Depok: Univeristas Indonesia,

Agustiawan (2018) Kementerian Riset, Teknologi, Dan Pendidikan Tinggi Institut Seni Indonesia Yogyakarta Upt Perpustakaan.

Arsip Nasional RI. (2006). Rekonstruksi Penyelamatan Arsip Badan Pertahanan Nasional NAD, Media Kearsipan nasional, Edisi 46.

Arsip.ui.ac,id/node/33, Di Akses Pada Tanggal 27 februari 2020. 
Boedi Martono. (1990). Sistem Kearsipan Praktis. Jakarta: Pustaka Sinar Harapan.

Badan, D. I., \& Dan, P. (2015). Perencanaan kesiapan menghadapi bencana gempa sebagai bagian kebijakan pelestarian bahan pustaka di badan perpustakaan dan kearsipan provinsi sumatera barat. (September), 148-159.

Ii, B. A. B., \& Teori, L. (n.d.). No Title. 19-60.

Karmidi Martoatmodjo. (1999). Pelestarian Bahan Pustaka. Jakarta: Universitas Terbuka.

Ladiawati, Dewi. (2007) Pelestarian Arsip, Menyelamatkan Warisan Budaya Bangsa, Jakarta: Jurnal Anri. Vol. 2

National Archieves (2020). Preservation. Di Unduh Pada Tanggal 27 Februari 2020. From http://www.archives.gov/preservation

Nurzannah, S., Perpustakaan, J. I., Adab, F., Humaniora, D. A. N., Islam, U., \& Syarif, N. (2017). Pelestarian arsip kertas dengan metode enkapsulasi di arsip nasional republik indonesia.

Safri, T. M. (n.d.). Strategi Preservasi Digital di Perpustakaan STMIK AMIKOM Yogyakarta. 84-96.

Verry Mardiyanto. (2016). Khazanah Jurnal Pegembangan Kearsipan. Strategi Kegiatam Preservasi Arsip Terdampak Bencana:Lokasi Kasus Di Arsip Nasional Republik Indonesia.

Wigati, F. A., \& Rachman, M. A. (2019). Identifikasi Perlindungan Arsip Statis Terhadap Bencana Kebakaran : Studi Kasus DI. $9008(21)$.

Yayan Daryana, K. dasar pemeliharaan dan pengamanan A. (n.d.). Konsep Dasar Pemeliharaan dan Pengamanan Arsip. 